\title{
Editorial: PIA Volume 22
}

\author{
Thomas J. T. Williams*
}

It is axiomatic of capitalist society that the concept of value must inevitably be reduced down to a single monetary index. In other words, we have come to expect that, in final analysis, economic value trumps all others. In the last couple of years we have seen this most clearly expressed in the government's attitude to forestry. The historical reluctance of officaldom to recognise value of a more intangible kind also lies at the heart of the tension in cultural heritage management between the historic environment and the pressure placed on its guardians to exploit or ignore those assets in favour of economic priorities. Alia Wallace's paper on Pompeii in this journal (p. 115) demonstrates the realities of what is - at best - a strained compromise between the demands of conservation and tourism. Elsewhere, heritage assets find themselves in the hands of organisations for whom their care is at best a distraction from their primary responsibilities: such is the nature of the rich but problematic architectural heritage of the London Underground, and Kate Fulcher's paper on the conservation of the network's tiling unpacks the inherent tensions (p. 48).

Both these papers reinforce many of the points made at the Archaeology and Economic Development Conference (21-22 September 2012) - covered here in detail by two of our editors: Hana Koriech and Colin Sterling (p. 158). The conference review provides highly relevant global context for this issue's forum. Joe Flatman and Dominic Per-

\footnotetext{
* UCL Institute of Archaeology 31-34 Gordon Square, London WC1H OPY United Kingdom, t.williams.09@ucl.ac.uk
}

ring have contributed a lead article which considers the potential impacts - good and bad - of the new National Planning Policy Framework (NPPF) on archaeology and heritage management (p. 4). Their article, and the responses which follow, express a cautious optimism about many aspects of the new legislation. Perhaps one of the reasons why the NPPF came as a welcome surprise is down to the many changes that have been implemented to the document over its draft form. One cannot help but suspect that the draft NPPF was promulgated as a ploy to ensure that its revised version would be met with an enthusiasm born of relief. Nevertheless, the protection of the principle of developed-funded excavation is - as many of our forum contributors remark - entirely welcome, as is the recognition of the value and interconnectedness of natural, historic and social environmental assets. That - given the sort of society we inhabit - is perhaps the greatest, and most surprising, cause for optimism; it represents a potential shift in the way that official opinion regards the value of the environment as a whole.

In his lengthy interview with PIA, the Institute's latest Professorial appointment - Mike Parker Pearson - recalls the shift from public to private investment in rescue archaeology and provides a useful perspective on the current trajectory of archaeological provision and heritage protection in the new planning guidance; as he points out, it is easy to look back on the 60s and 70s as a golden age for large-scale archaeology in this country, but the damage done to the historic fabric of British towns in those decades was tragic and unprecedented. It can only be hoped 
that the language of the NPPF crystallises in a permanent shift in attitudes that is able to withstand pressure from developers, legal challenges and inevitable clashes with the government's localism agenda.

Mike's interview is wide ranging and touches on a number of points that find resonance with other contributors to the journal. His longstanding involvement with Stonehenge - on the subject of which he provides many tantalizing new insights and promises of results and research to come - finds an echo in Antonio Silva's paper on the megalithic landscapes of Portugal (p. 99). Combining astronomy, archaeology, folklore and phenomenological approaches to landscape, Silva's paper is truly interdisciplinary and seeks to find ways to understand the mental world of people who have left no written records. In this, his approach takes particular inspiration from the post-processual movement in which Parker Pearson played a seminal role, and seeks to engage with what the latter describes as the hardest question to ever answer: 'why?' Similarly, research by Ester Oras seeks to understand the meanings that lay behind artefact deposition in the east Baltic iron-age. As her paper illustrates, the tools with which such an investigation is undertaken - in this case terminological - can be of crucial importance for making meaningful progress (p. 61).

Elsewhere, Pamela Lofthouse presents an article on the development of the quintessential symbol of British suburbanism: the humble semi (p. 83). Her paper makes an interesting companion to last issue's article on the allotment garden, and serves as a reminder that our heritage is all around us, no matter how familiar. A range of other exhibition and conference reviews round out another substantial and diverse collection from the cutting edge of post-graduate archaeology.

\section{Tom Williams}

PIA Editor

December 2012 